\title{
Дондик Л.Ю. \\ Формирование аудитивных умений иностранного языка на уровне начального общего образования
}

Российский государственный профессионально-педагогический университет (Россия, Нижний Тагил)

doi: $10.18411 / \mathrm{lj}-05-2021-227$

\section{Аннотация}

В данной статье рассматривается проблема формирования аудитивных умений иностранного языка на уровне начального общего образования. Излагаются результаты теоретического обобщения литературы по психологическому и методическому аспектам аудирования. Анализируются условия организации эффективного развивающего обучения аудированию на уровню начального общего образования.

Ключевые слова: аудирование, аудитивные умения, первичные умения, дотекстовый и послетекстовый этапы аудирования, визуальные опоры, развивающее обучение.

\section{Abstract}

This article examines the problem of the formation of auditory skills of a foreign language at the level of primary general education. The results of theoretical generalization of literature on the psychological and methodological aspects of listening are presented. The conditions for the organization of effective developmental teaching in listening at the level of primary general education are analyzed.

Keywords: listening, auditory skills, primary skills, pre-text and post-text stages of listening, visual aids, developmental learning.

За последние десятилетия произошло изменение статуса школьного предмета «Иностранный язык». С развитием процессов глобализации повысилась значимость английского языка как инструмента международной деятельности, как средства общения, достижения понимания и взаимодействия людей, средство приобщения к иной национальной культуре. С тех пор, как иностранный язык стал массово изучаться на уровне начального общего образования, пришло осознание его и как важного средства развития интеллектуальных способностей учащихся, социализации и самореализации личности ребенка, осознание его общеобразовательного потенциала.

Целью обучения иностранному языку на уровне начального общего образования является формирование у обучающегося элементарных первичных умений, необходимых для дальнейшего формирования и развития иноязычной коммуникативной компетенции как инструмента межкультурного общения в современном поликультурном мире. Без работы над формированием аудитивных умений не будет полноценным обучение иноязычному говорению, поскольку развитие этих языковых компетенций тесно связано.

Аудирование - это совершенно самостоятельный и специальный вид речевой деятельности, который можно охарактеризовать как перцептивную мыслительномнемическую деятельность [1]. Быстрый темп речи носителей английского языка и специфические особенности английского произношения, с одной стороны, и незрелость произвольных психических процессов младшего школьника, с другой стороны, - это объективные и субъективные факторы, осложняющие формирование первичных аудитивных умений на уровне начального общего образования. В то же время, анализ УМК по английскому языку, широко применяемых в нашей стране, свидетельствует о том, что проблеме формирования первичных умений аудирования на уровне начального общего образования, как правило, не уделяется достаточно внимание. Работа нередко сводится к прослушиванию аудиотекта с визуальной опорой на полный 
печатный текст, что со временем приводит к однобокому развитию аудитивных умений, к отставанию в уровне развития умений устной речи на иностранном языке от умений письменной речи (умения чтения). И такое отставание часто только усиливается при переходе на более высокие уровни образования.

Несмотря на то, что аудирование, как и чтение, классифицируют как рецептивную речевую деятельность, понимание иноязычной речи на слух немыслимо без встречной активной мыслительной деятельности слушающего [4, с.232]. Умение аудирования опирается на три группы навыков: а) грамматические навыки аудирования, или навыки неосознанного распознавания грамматических форм речи на морфологическом уровне и на синтаксическом уровне (упреждение структур) и их соотношение с определенным значением; б) лексические навыки аудирования, или навыки непосредственного понимания слов и словосочетаний; в) автоматизированные навыки восприятия и различения звуковой стороны речи: звуков, звукосочетаний, интонации [2, с.336]. Аудирование не является простой суммой указанных выше навыков, но это готовность применять эти навыки для понимания на слух каждый раз новых высказываний в новых коммуникативных ситуациях [3, с. 352].

Нормативные акты в сфере начального общего образования ориентируют учителей на использование системно-деятельностного подхода, при котором обучающийся уже на начальном этапе изучения иностранного языка должен овладеть первичными умениями такого сложного вида речевой деятельности, как аудирование. Обучающийся должен овладеть к концу 4 класса первичными умениями понимать основную информацию услышанного (небольшие тексты и сообщения, построенные на изученном речевом материале, как при непосредственном общении, так и при восприятии аудиозаписи); извлекать конкретную информацию из услышанного; понимать на слух разные типы текста (краткие диалоги, описания, рифмовки, песни); использовать контекстуальную или языковую догадку; не обращать внимания на незнакомые слова, не мешающие понимать основное содержание текста; уметь вычленять главное и второстепенное из услышанного [6].

Для эффективной организации обучения аудированию необходим учет возрастных особенностей обучающихся на уровне начального общего образования, определяющих многие затруднения, которые возникают при понимании иноязычной речи на слух. Большое значение имеет учет значительного количества психофизиологических механизмов, задействованных при восприятии иноязычной речи на слух: механизма внутреннего проговаривания, оперативной памяти, внимания, осмысления, антиципации, сличения - узнавания и многих других. Психические процессы активно развиваются у младшего школьника, но пока далеки от совершенства. С одной стороны, успешность выполнения аудирования зависит от уровня сформированности этих механизмов, а, с другой стороны, работа по обучению аудированию способствует совершенствованию психических процессов обучающегося.

Работу над аудированием, с точки зрения методики, целесообразно организовывать в три этапа: а) дотекстовый этап как предварительная инструкция, которая создает мотивационную и организационную установку, мобилизует на активную работу; б) прослушивание аудиотекста (прослушиваний может быть несколько, но, при этом важно не потерять мотивацию); в) послетекстовый этап, или контроль понимания услышанного. Наиболее типичные установки-задания для первого этапа работы с аудиотекстом: обсуждение вопросов/утверждений до прослушивания; догадка по заголовку/новым словам/иллюстрациям; краткое изложение основной темы учителем, введение в проблематику текста. Для второго этапа могут быть рекомендованы задания прослушать текст и вставить пропущенные слова в предложениях; прослушать текст и сказать, какие из предложенных словосочетаний употреблялись в нем без каких-либо изменений; прослушать текст и сказать, какие определения к следующим словам в нем встречались; закончить предложения; 
прослушать текст и сказать, что в нем говорилось о чем-либо. Для проверки понимания текста могут применяться задания на понимание содержания прослушанного; задания на творческую переработку воспринятой информации; задания на использование полученных сведений в общении и других видах деятельности [4].

C методической точки зрения для организации учебной работы по формированию аудитивных умений обучающихся на уровне начального общего образования может быть рекомендовано при отборе учебного материала обращать внимание на объем речевых сообщений, на темп речи говорящего, а также на наличие опор и ориентиров восприятия в звучащем тексте. Для эффективного обучения аудированию рекомендованы тексты из 3-6 предложений описательного характера до 3 минут звучания. Желательно, чтобы ключевая информация в сообщении проговаривалась медленнее, чем второстепенная. Успешность аудирования во многом зависит от того, какими ориентирами сопровождается воспринимаемый на слух текст, а также имеются ли в нем опоры для запоминания. Важно обучать младших школьников выделению на слух смысловых ориентиров с опорой на интонацию (как признак связи слов и предложений), ритм, паузы и логическое ударение. В текстах для аудирования на уровне начального общего образования речь должна быть выразительной и содержать экспрессивные средства, выражающие эмоциональное отношение говорящего к сообщаемым фактам, явлениям. Большую помощь обучающемуся могут оказать речевые штампы (клише), если, конечно, ранее проводилась работа по освоению такой лексики [5]. Характер опор меняется в зависимости от речевого опыта. На начальном этапе обучения должны использоваться учебные аудио- и видеозаписи для обучения аудированию как контактной, так и дистантной речи на иностранном языке. При комбинированном звукозрительном предъявлении более сложных для понимания дистантных речевых сообщений рекомендованы визульные подсказки (цветовое и шрифтовое выделение ключевой информации, схемы, картинки, заголовки), поскольку «пропускная способность» слухового анализатора во много раз меньше зрительного [5, с. 247]. Визуально-изобразительная опора разгружает память, способствует структурированию речевого потока.

Итак, аудирование, наряду с говорением, обеспечивает возможность общения на иностранном языке, так как речевое общение - процесс двусторонний. Чтобы сделать доступным для младшего школьника обучение такому сложному виду речевой деятельности на иностранном языке, учителю следует обращать внимание на ряд факторов, позволяющих снять отдельные трудности для младшего школьника: темп речи говорящего, наличие различных опор, количество предъявлений, объем речевых сообщений. Обучение аудированию имеет большой развивающий потенциал, так как способствует формированию многих метапредметных умений и качеств личности, необходимых для социализации обучающегося. Это объясняется тем, что сам процесс восприятия речи на слух предусматривает запоминание различных видов текстов, что улучшает память и развивает кругозор, использование метафорических выражений, что тренирует воображение и внимание, и, наконец, развивает умение слушать и понимать услышанное, что воспитывает внимательность к собеседнику.

$$
* * *
$$

1. Артемов В. А. Психология обучения иностранным языкам / В. А. Артемов. Москва : Педагогика, 2002. 272c.

2. Гальскова Н. Д. Теория обучения иностранным языкам. Лингводидактика и методика / Н. Д. Гальскова, Н. И. Гез. Москва : ACADEMIA, 2006. 336 с.

3. Комков И. Ф. Методика преподавания иностранным языкам / И.Ф. Комков. Минск : Вышэйшая школа, 1983. 352c.

4. Рогова Г. В. Методика обучения английскому языку на начальном этапе в общеобразовательных учреждениях / Г. В. Рогова, И. Н. Верещагина. Москва : Просвещение, 2000. 232 с. 
5. Синева Ю. О. Обучение аудированию на начальных этапах обучения иностранному языку / Ю. О. Синева, О. А. Крапивкина // Вестник Иркутского Государственного Технического Университета, 2015. № 10. C. 245-249 [Электронный pecypc] - URL: https://www.cyberleninka.ru/article/v/obuchenie-audirovaniyu-na-nachalnyhetapah-obucheniyainostrannomu-yazyku (дата обращения: 06.02.2021).

6. Федеральный государственный образовательный стандарт начального общего образования / Министерство образования и науки Российской Федерации. Москва : Просвещение, 2010. 31 с.

\section{Дьячкова А.Д., Каминская Л.А. \\ Анализ гематологических и биохимических показателей крови у больных Covid- 19, влияние дексаметазона}

ФГБОУ ВО Уральский государственный медицинский университет (Россия, Екатеринбург)

doi: $10.18411 / \mathrm{j}-05-2021-228$

\section{Аннотация}

В статье обсуждаются результаты ретроспективного анализа гематологических и биохимических показателей крови 20 больных Covid-19 мужского пола, возраст $(66,9 \pm 4,7)$ лет. Сформированы две группы: лечение в соответствии с протоколом без дексаметазона и с дексаметазоном. К окончанию лечения применение дексаметазона вызывает достоверное снижение показателя С -реактивного белка (СРБ), повышение уровня эритроцитов и глюкозы $(\mathrm{p}<0,01)$ в сравнении с группой больных, не получавших дексаметазон. На фоне применения дексаметазона метод парных корреляций выявляет связь воспаления (показатель СРБ) с уровнем тромбоцитов (r= $0,79)$ - обратная связь, изменеиием активности АЛТ крови $\quad(\mathrm{r}=+0,85)$; средней силы связи с уровнем лейкоцитов $(\mathrm{r}=+0,47)$, и активности $\mathrm{ACT}(\mathrm{r}=+0,47)$. Прямые связи для ферментов АЛТ и АСТ с СРБ подтверждают ответ печени на воспаление.

Ключевые слова: COVID-19, дексаметазон, гематологические, биохимические показатели, корреляция.

\section{Abstract}

The article discusses the results of a retrospective analysis of hematological and biochemical blood parameters of 20 male patients with Covid-19, age $(66.9 \pm 4.7)$ years. Two groups were formed: treatment according to the protocol without dexamethasone and with dexamethasone. By the end of treatment, the use of dexamethasone causes a significant decrease in the C-reactive protein (CRP), an increase in the level of erythrocytes and glucose $(\mathrm{p}<0.01)$ in comparison with the group of patients who did not receive dexamethasone. Against the background of the use of dexamethasone, the method of paired correlations reveals the relationship between inflammation (CRP indicator) and the level of platelets $(\mathrm{r}=-$ $0.79)$ - feedback, changes in the activity of ALT in the blood $(r=+0.85)$; average strength of connection with the level of leukocytes $(r=+0.47)$, and AST activity $(r=+0.47)$. Direct links for the enzymes ALT and AST with CRP support the liver's response to inflammation.

Key words: COVID-19, dexamethasone, hematological, biochemical parameters, correlation.

Распространение COVID-19 создало задачи быстрой диагностики и быстрой медицинской помощи больным. Наиболее распространенным клиническим проявлением является двусторонняя пневмония (вирусное диффузное альвеолярное повреждение с микроангиопатией), у 3-4\% пациентов зарегистрировано развитие острого респираторного дистресс-синдрома, у ряда больных развивается гиперкоагуляционный синдром с тромбозами и тромбоэмболиями, поражаются также 